\title{
Putting the House of Wisdom in Order: Why the Fourth/Tenth Century?
}

\author{
Weaver, James ; Osti, Letizia ; Rudolph, Ulrich
}

DOI: https://doi.org/10.1515/asia-2017-0056

Posted at the Zurich Open Repository and Archive, University of Zurich ZORA URL: https://doi.org/10.5167/uzh-148403

Journal Article

Published Version

Originally published at:

Weaver, James; Osti, Letizia; Rudolph, Ulrich (2017). Putting the House of Wisdom in Order: Why the Fourth/Tenth Century? Asiatische Studien / Études Asiatiques, 71(3):767-770.

DOI: https://doi.org/10.1515/asia-2017-0056 


\section{James Weaver*, Letizia Osti and Ulrich Rudolph Putting the House of Wisdom in Order: Why the Fourth/Tenth Century?}

https://doi.org/10.1515/asia-2017-0056

The fourth Islamic century/tenth century CE witnessed a proliferation of texts concerned with organizing and making accessible both the scientific and literary production of early Arabic-Islamic scholarship and that of the pre-Islamic societies whose intellectual heritage had entered its purview. Some authors pursued greater comprehensiveness in compiling, arranging, editing and commenting within individual disciplinary traditions; some assembled and repackaged material from across a wide range of different subjects; and some focused on the topography of human knowledge itself, mapping its distinct parts and describing their content. These efforts are apparent in a diverse body of literature: the bibliophiles' ordered inventories of books and authors; the topically diverse administrative manuals of the bureaucrats; the summae of the lawyers and theologians; and the numerous treatises on the classification of knowledge of the philosophers. Of course, neither reflection on the structure of knowledge, nor the effort to summarize and arrange it in usable fashion were new to ArabicIslamic scholarship in the fourth/tenth century: the extant works of al-Kindi attest well to the former, and we need only to think of the canonical hadithcollections of the third century for an example of the latter. Just as obviously, the year 400 did not mark an end to such activities. Nevertheless, the concentration of texts dealing with the surveying, inventorying and classifying of knowledge produced in this period is striking and merits investigation from the point of view of its practical and intellectual motivations, as well as the social institutions and technologies involved.

To the extent that this phenomenon has been approached already, this has been done in a somewhat piecemeal fashion. Whilst we have numerous valuable studies of individual works from the period, the broader trends of the fourth/

*Corresponding author: James Weaver, Universität Zürich, Asien-Orient-Institut, Rämistrasse 59, 8001 Zürich, Switzerland. E-mail: james.weaver@uzh.ch

Letizia Osti, Dipartimento di Scienze della Mediazione Linguistica e di Studi Interculturali, Università degli Studi di Milano, Piazza Indro Montanelli, 1, I-20099, Sesto San Giovanni Milano, Italy

Ulrich Rudolph, Universität Zürich, Asien-Orient-Institut, Rämistrasse 59, 8001 Zürich, Switzerland 
tenth century are often dealt with only in passing, in the context of chronologically wide-ranging enquiries into Arabic-Islamic "encyclopaedism." The most recent of these is the important collection of papers edited by Gerhard Endress in Organizing Knowledge: Encyclopaedic Activities in the Pre-Eighteenth Century Islamic World. ${ }^{1}$ That volume brings together contributions from scholars of Arabic and Islamic Studies, along with a valuable regard oblique from Anne Blair, whose essay highlights several crucial and underexplored questions for the Arabic textual tradition in comparison with the state of research on similar phenomena in Medieval, Renaissance and Early Modern Europe. ${ }^{2}$

Indeed, whilst the kind of longue durée approach that takes the whole of the pre-modern Islamic period into account provides an important perspective, what we have lacked is precisely the kind of study for which Blair herself is rightly famous: chronologically focussed enquiries into the specific intellectual-historical circumstances in which particular kinds of compilatory literature were produced, combined with the detailed analysis of the design and intended function of numerous individual works. Lately, there has been a move precisely in such a direction. In this, as in so much else, it is the Mamlūkists leading the way, demonstrated above all by recent contributions from Elias Muhanna and Maaike van Berkel. ${ }^{3}$ In our case, this leads to the concentration on the fourth/ tenth century.

Approaching such a multi-faceted phenomenon-even once chronologically bounded-being a task that demands expertise in numerous areas, it seemed that a workshop would be a helpful way of initiating a response. Hence, a group of researchers working on various topics in the intellectual history of the fourth century were brought together in Zurich in February 2016 for a workshop entitled Putting the House of Wisdom in Order: the fourth Islamic century and the impulse to classify, arrange and inventory. We also profited from the expertise of renowned specialists in the cultural history of China and Early Modern Europe, Alessandra Lavagnino and Peter Burke, who helped us identify common questions and participated actively in the workshop. The conversations at the workshop were varied and fruitful and, as was to be expected, yielded more questions than answers. The papers in the present volume of Asiatische Studien - Études Asiatiques represent a selection of those delivered at the workshop and reflect that variety, whilst also highlighting a range of themes that emerged repeatedly.

1 Endress 2006.

2 Blair 2006.

3 Muhanna 2012 and 2013; van Berkel 2013. 
Several contributors demonstrated that one of the preoccupations of writers who sought a more structured presentation of their material in books was didactic. The links between the systematisation of knowledge and the systematisation of learning in general deserve further discussion and the papers presented here from Natalia Bachour and Johannes Thomann both touch on this question. Bachour describes the use of lexicographical techniques in the composition of medical dictionaries aimed at the student, whilst Thomann analyses the fourth century revival of astronomical teaching and the influence of the pedagogical methods involved on the structure of surviving astronomical literature.

Lale Behzadi's and Julia Bray's papers discuss how the challenge of classification is not the preoccupation only of philosophers and scientists, but must be confronted also in less technical endeavours: Behzadi invites us to consider the frameworks for classifying emotions in al-Tanūkhī's collection of stories dealing with "deliverance after hardship", whilst Bray explores our use of the category "exotic" in the reading of al-Tanūkhī's writings on India and elephants.

Over the course of the workshop, it became clear that the impetus to classify and arrange that was drawn from the content, structure and ideals of the translated Greek, Persian and Indian works cannot be ignored. This idea features prominently in the contributions of Antonella Ghersetti and Godefroid de Callataÿ. Ghersetti describes how concepts in Greek logic were incorporated into the study of Arabic Grammar, whilst de Callataÿ explores the relationship between the various classifications of the sciences on offer in the Epistles of the Brethren of Purity and discusses their likely antecedents.

Another common theme was whether some of the concepts through which we analyse the literature of this period have themselves become hindrances, compelling us to focus only on narrow aspects of the texts involved. From this perspective, James Weaver explores the various usages of the term encyclopaedia in respect of fourth century literature and questions how useful they are for our understanding of the intellectual history of the period. We are pleased to be able to round off the selection of papers with regards obliques from Alessandra Lavagnino and Peter Burke.

Finally, we would like to take this opportunity to express our gratitude to all of the speakers, discussants and attendees at the workshop whose contributions are not made visible in this publication, as well as to thank our sponsors: The Swiss National Science Foundation, the Swiss Academy of Humanities and Social Sciences, the University of Zurich Research Priority Program Asia and Europe, and the Zürcher Universitätsverein.

James Weaver, Letizia Osti and Ulrich Rudolph Zurich, July 2017 


\section{Bibliography}

van Berkel, Maaike (2013): “Opening up a World of Knowledge: Mamlūk Encyclopaedias and Their Readers". In: Encyclopaedism from Antiquity to the Renaissance. Edited by Jason König and Greg Woolf. Cambridge: CUP, 357-376.

Blair, Ann (2006): “A Europeanist's Perspective”. In: Organizing Knowledge: Encyclopaedic Activities in the Pre-Eighteenth Century Islamic World. Edited by Gerhard Endress. Leiden: Brill, 201-215.

Endress, Gerhard (ed.) (2006): Organizing Knowledge: Encyclopaedic Activities in the PreEighteenth Century Islamic World. Edited by Gerhard Endress. Leiden: Brill.

Muhanna, Elias (2012): Encyclopaedism in the Mamluk Period: The Composition of Shihāb alDīn al-Nuwayrī’s (d. 1333) Nihāyat al-'Arab fĩ Funūn al-Adab. PhD. Diss. Harvard.

Muhanna, Elias (2013): "Why Was the Fourteenth Century a Century of Arabic Encyclopaedism". In: Encyclopaedism from Antiquity to the Renaissance. Edited by Jason König and Greg Woolf. Cambridge: CUP, 343-355. 